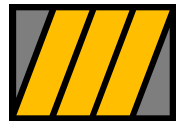

ESCUELA DE NEGOCIOS

Universidad Torcuato Di Tella

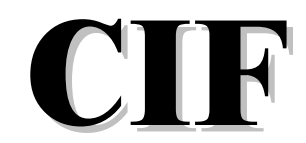

Centro de Investigación en Finanzas

Documento de Trabajo 11/2004

\title{
Dollars, Debt and the IFIs: Dedollarizing Multilateral Lending
}

Eduardo Levy Yeyati

Universidad Torcuato Di Tella
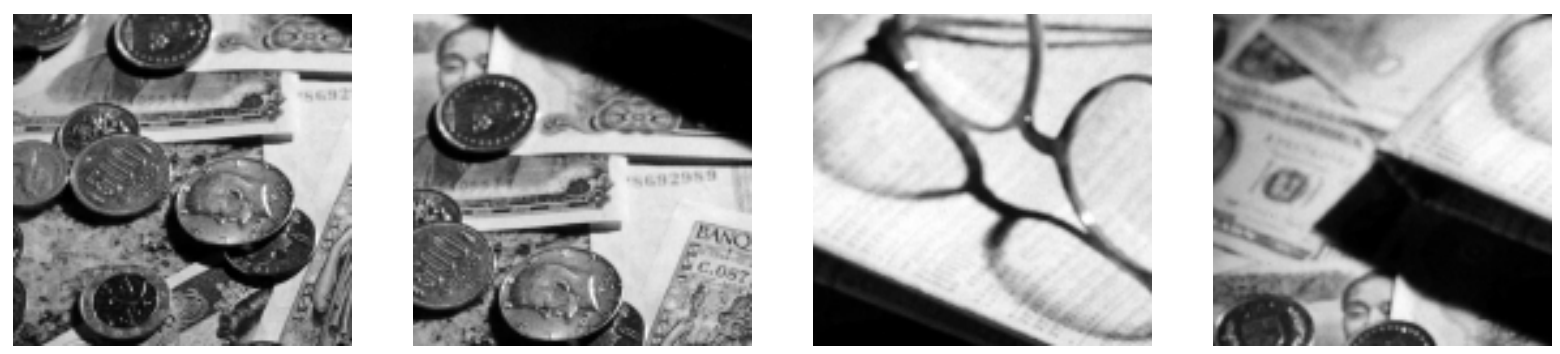

Miñones 2177, C1428ATG Buenos Aires • Tel: 4784.0080 interno 181 y 4787.9394 - Web site: www.utdt.edu/departamentos/empresarial/cif/cif.htm 


\title{
Dollars, Debt and the IFIs: Dedollarizing Multilateral Lending
}

\author{
Eduardo Levy-Yeyati ${ }^{1}$ \\ Business School \\ Universidad Torcuato Di Tella
}

This version

September 30, 2004

\begin{abstract}
Financial dollarization (FD) has been increasingly seen as a concern due to its negative impact on crisis propensity and output volatility, shifting the center of the FD debate towards a more proactive dedollarization stance. While often neglected, lending from International Financial Institutions (IFIs) is an important source of FD in emerging economies, and as such a dimension that cannot be overlooked by any dedollarization strategy. This paper revisits old and new arguments in favor of IFI lending in the local currency, and argues that any such initiative should rely, at least at an early stage, on the demand from residents in search for stable returns in units of the local consumption basket, but reluctant to take on sovereign risk. Due to their superior enforcement capacity, IFIs can intermediate these savings, currently invested in dollarized foreign assets, back into the local economy by offering investment grade local currency bonds and using the proceeds to dedollarize their own lending to non-investment grade countries, thereby contributing to reduce FD while fostering the development of local currency markets.
\end{abstract}

\footnotetext{
${ }^{1}$ The author wants to thank Eduardo Fernández Arias and Esteban Molfino for fruitful discussions and suggestions, and Daniel Chodos and Ramiro Blazquez for their excellent research assistance.
} 


\section{Introduction}

Financial dollarization (FD) has been placed increasingly at the forefront of the policy debate in many emerging economies, driven by concerns about the currency imbalance and the associated financial fragility that it introduces for the economy as a whole. ${ }^{2}$ As a result, the center of the FD debate has moved from a generally passive stance aimed at minimizing its negative implications, to a more proactive one oriented to offset the incentives that favor dollarization while developing local currency substitutes. ${ }^{3}$

While the debate has tended to center on the propensity to save in a foreign currency and the limitations to borrow internationally in the local currency, one of the most important sources of FD in emerging economies is their dependence on lending from international financial institutions (IFIs), which has been historically denominated in a basket of hard currencies. It follows that any dedollarization strategy should in principle encompass the particular issue of the denomination of multilateral lending, not only due to its implications regarding the country's overall currency mismatch but also as a potential ingredient conducive to the development of a market for local currency securities of long duration. Indeed, the convenience of dedollarizing part of the lending granted by IFIs has already been highlighted in recent proposals (see, e.g., Eichengreen and Hausmann, 2002). However, for a number of reasons, these ideas have been received with skepticism or indifference by market practitioners and IFI staff.

The present paper redresses this issue, by identifying and discussing old and new theoretical and practical arguments in favor and against IFI lending in local currency. In particular, and in contrast with the existing proposals that stress the potential demand from non-residents seeking a currency-diversified portfolio, this paper argues that any

\footnotetext{
${ }^{2}$ In what follows, following what has become standard in the dollarization literature, "dollar" and "foreign currency", and "peso" and "local currency" are used interchangeably.

${ }^{3}$ In this context, dedollarization is understood as a voluntary process, as opposed to a compulsory currency conversion. For an overview of the financial dollarization and dedollarization debates, see the papers presented in the IADB/World Bank Conference on Financial Dedollarization: Policy Options, December 12, 2003, at http://www.iadb.org/ros/DeDolarizacion/Agenda.htm.
} 
such initiative should (and realistically can) rely, at least at an early stage, on the demand from emerging market residents in search for local currency assets that minimize the volatility of returns measured in the local consumption basket, but reluctant to take on sovereign risk. In line with this view, the paper suggests a more limited approach to dedollarizing multilateral lending that may overcome some of the obstacles inhibiting their practical implementation while serving as a first step towards the more ambitious initiatives already on the table.

Saving in the local currency faces two fundamental obstacles in developing countries: high nominal volatility (that is, unpredictable inflation due to nominal shocks or, most notably, to attempts to dilute the real value of local currency liabilities through inflation), and high credit risk (that is, a high probability of default, including through the violation of the terms and conditions of both public and private contracts under local jurisdiction, or the imposition of confiscatory taxes on the stock of savings).

The first obstacle can be largely mitigated through the use of indexation, typically to the CPI, which limits the incentives for debt dilution. The second obstacle is more difficult to tackle. Country risk encompasses not only the possibility of outright default by a particular debtor but also a number of sovereign actions that negatively affect creditor rights. Both the index and the terms and conditions of contracts can suffer unexpected and undesired modifications, such as an involuntary currency conversion or debt restructuring, due to the intervention of local institutions.

These risks, in turn, generate incentives to relocate savings in countries where property rights are better defined and protected. Thus, even in the absence of nominal instability (or despite the mitigating presence of indexation), residents may end up dollarizing their savings simply because of the lack of local currency assets free from country-specific credit risk. Under these conditions, there is a potential demand of investment-grade securities in local currency that cannot be satisfied by non-investment grade countries. 
As a large part of the domestic pool of savings moves abroad as a result, the country is forced to rely on foreign (and, in particular, multilateral) credit. ${ }^{4}$ IFIs can in practice make up (at least partially) for the lack of domestic funds due to their greater ability to enforce the contractual terms where private creditors fail, which enables them to collect funds and issue loans at close to risk-free rates to countries facing high country risk premiums. Thus, by means of their preferred creditor status, they are able to mitigate the agency problems underscoring the high cost of capital in emerging economies, playing a "risk transformation" role.

In this light, the IFIs are natural candidates to launch the investment-grade local currency market. By issuing debt in emerging market currencies to fund local currency loans to emerging countries, they could dedollarize an important portion of the country's external liabilities (converting existing IFI loans into the local currency while keeping a balanced currency position), thereby providing the needed liquidity to start up these missing markets. ${ }^{6}$

The main deterrent to advance with this type of initiatives has been the untested conjecture that the representative international investor would not be attracted by local currency assets. However, the minimum liquidity needed to launch markets for investment-grade local currency securities can be obtained from a latent demand for these securities coming from the country's residents.

The FD literature has made, both analytically and empirically, a distinction between residents and non-residents as potential demanders of local currency assets. Analytically,

\footnotetext{
${ }^{4}$ de la Torre and Schmukler (2003) discuss offshorization as a mechanisms to cope with country-specific risk. If offshorization could successfully protect from country risk, foreign borrowing could readily substitute for the decline in domestic funds. However, the extent to which offshore claims are less exposed to country-specific risk than onshore assets is not obvious, as witness the recent Argentine default.

${ }^{5}$ IFIs also benefit from the implicit guarantee provided by their member countries, although the incidence of these guarantees on the costs of their lending to emerging economies is difficult to assess in the absence of default episodes.

${ }^{6}$ Indeed, if we accept that financial dollarization is a source of financial fragility, the partial dedollarization of their lending would, at best, reduce their exposure to sovereign risk. Needless to say, this argument as well as much of the discussion below applies primarily to multilateral development banks, as opposed to institutions like the IMF that are not funded in the market.
} 
instruments denominated in the local currency will look relatively more attractive to riskaverse local savers (borrowers), as they mirror their stream of future consumption (income) more closely. ${ }^{7}$ Empirically, there is evidence that shows that past debt dedollarization processes have been largely driven by a deepening of the domestic markets based on local demand. ${ }^{8}$

On the other hand, some observers have argued that, inasmuch as domestic currency mismatches tend to cancel out, the negative consequences of FD are specifically driven by the country's foreign currency position vis à vis non-residents, which would cast doubt on the benefits of a strategy focused on resident demand. ${ }^{9}$ However, the evidence indicates that currency mismatches between residents do not net out in the aggregate, and can be as harmful as external liabilities in terms of the aggregate real exchange rate exposure. ${ }^{10}$ Moreover, as this paper will argue, targeting the stock of foreign assets held by residents (including local institutional investors) may lead to a substitution of local currency domestic debt for foreign currency external debt, reducing the measured aggregate position of the country. ${ }^{11}$

The case of pension funds is illuminating. By acquiring a credit risk-free asset denominated in CPI units, fund managers would fulfill their role by ensuring a stable stream of retirement benefits while avoiding the risk of confiscation. However, in order

\footnotetext{
${ }^{7}$ This distinction was originally made by Thomas (1985) in a two-country setup and, more recently, in Ize and Levy-Yeyati (2003).

${ }^{8}$ Bordo et al. (2002), analysing the evolution of debt denomination in four British Dominions (Canada, Australia, New Zealend and South Africa), highlight that "the onset of World War I essentially closed the London capital market, and the response was similar in all four Dominions. The gold convertibility of the domestic currency was suspended (and not resumed until 1925) and governments raised funds domestically, essentially creating a domestic bond market. Foreign capital (at least for sovereign debt) would never regain to the same extent." Similarly, Claessens et al. (2003) find that the dollarization ratio of (domestic plus external) government bonds is negatively related with the size of domestic financial markets. See also Martínez and Werner (2002), Herrera and Valdez (2003), and Caballero et al. (2003), for the development of local currency markets in Mexico, Chile and Australia, respectively.

${ }^{9}$ See, e.g., Eichengreen at el. (2003).

${ }^{10}$ For example, Berganza and García Herrero (2004) find that the incidence of balance sheet effects on country risk arising from domestic deposit dollarization are comparable to those related with external foreign currency debt. Levy-Yeyati (2004) and Levy-Yeyati et al (2004) report similar results for banking fragility and crisis propensity.

${ }^{11}$ The stock of foreign assets held by residents is typically ignored while computing the aggregate currency mismatch.
} 
to diversify credit risk, pension funds typically invest a fraction of their portfolio in dollarized foreign assets. As a result, while the emerging country government borrows in dollars from IFIs, a share of residents' retirement savings is invested abroad in dollarized investment grade paper (such as that issued by IFIs to fund their own lending). It is immediate to see how IFIs may intermediate these funds by selling to pension funds the bonds that finance the country loans, and how this intermediation could be done in CPI units to the benefit of both parties involved.

This paper argues that this type of arrangement is a natural first step to dedollarize the external debt of developing countries. The advantages of the scheme are several. First, it partially dedollarizes the liabilities of the country, voluntarily and with no cost for the local investor (who acquires an risk-free asset in a unit of account that minimizes the relevant volatility of future returns) nor for the IFIs (which manage to keep a balanced currency position). ${ }^{12}$ Second, it starts up an international market in local CPIs that can be used as a benchmark by domestic borrowers seeking to avoid the real exchange rate exposure characteristic of foreign currency borrowing at a reasonable cost. Third, it could eventually attract funds from non-residents willing to hold a speculative position in the local currency without assuming excessive risk or, when and if exotic currency markets develop, in search for currency diversification.

The plan of the paper is as follows. Section II, succinctly revisits the literature on FD, highlighting the relative importance of IFI lending vis à vis other sources of financial dedollarization. Section III extends the model in Ize and Levy Yeyati (2003) to derive analytically the link between country risk, offshorization of residents' savings and FD, and reports preliminary evidence in line with the analytic results. Section IV evaluates the menu of options already being provided by IFIs to reduce currency mismatches, reviews the arguments for and against previous proposals to dedollarize IFI lending, and elaborates on alternative ways to pursue this goal. Section V concludes.

\footnotetext{
${ }^{12}$ Strictly speaking, currency risk would still affect the financial income of the IFI. Arguably, this is a very minor risk cost that can be priced in the loan.
} 


\section{Definitions, implications and measurement}

In this paper, financial dollarization simply denotes the holding by residents (including the public sector) of foreign currency-denominated financial assets and liabilities. The phenomenon, which have received quite a lot of attention in the literature, ${ }^{13}$ has been increasingly seen as a source of concern for a number of reasons, most notably the incidence of the associated currency mismatch on output volatility and financial fragility.

These concerns have been validated by recent empirical work. Berganza et al. (2003) find that the response of sovereign spreads to exchange rate changes increases with the degree of external FD, while Berganza and García Herrero (2004) show that this effect is driven largely by exchange rate depreciations (in line with the balance sheet view) both when dollarization is external (measured as external obligations over GDP) or domestic (proxied by the ratio of dollarized onshore deposits over GDP). In turn, Domac and Martínez Pería (2000) find the foreign-liabilities-to-assets ratio of local banks to be positively correlated with the probability of a systemic banking crisis. Along this lines, Levy Yeyati (2004) finds that the propensity to face a banking crisis after a depreciation of the local currency increases with the degree of FD of domestic banking institutions. Finally, the evidence suggests that FD also has important consequences for the real economy, through its association with a higher propensity to suffer sharp capital account reversals or "sudden stops" (Calvo et al., 2004) and slower and more volatile growth rates (Levy Yeyati, 2004).

The definition and measurement of FD in its different varieties is still subject to discussion (see Eichengreen et al. (2003) and Goldstein (2003)). While the literature has tended to emphasize the country's foreign currency position vis a vis non-residents

\footnotetext{
${ }^{13}$ Existing explanations of FD point at portfolio hedging considerations (Ize and Levy Yeyati, 2003), time inconsistency problems related to the temptation to dillute peso obligations through inflation (Calvo and Guidotti, 1989), the incidence of implicit debtor guarantees (Burnside et al., 2001), currency-blind financial regulation (Broda and Levy Yeyati, 2003) and signaling problems (De la Torre et al., 2003), among others. See De Nicoló et al. (2003) for a discussion and empirical testing of some of these hypotheses.
} 
(typically measured by its foreign currency-denominated external debt), ${ }^{14}$ the aggregation argument underlying this distinction (namely, that the currency exposure of resident creditors and debtors should cancel out) ignores important aggregate effects. Even if a financially dollarized economy is currency-balanced as a whole, it will likely be imbalanced at a micro level, leading to capital flight, bank runs and massive bankruptcies at the time of a real exchange rate adjustment, with important real consequences. Hence, the significant effects of domestic FD found in the literature.

Moreover, a simple portfolio approach (as the one adopted in the next section) suggests that the degree of domestic and external dollarization should be intimately related. To the extent that the portfolio choice of resident savers determines the volume of peso loanable funds in domestic markets, it will be correlated with the dependence on dollarized foreign borrowing.

With this in mind, in this paper I look at both domestic and external sources of FD. Domestic dollarization is captured by onshore dollar deposits, which, given the standard prudential limits on banks' net currency position, provide a good proxy for the volume of onshore dollar loans. External dollarization, in turn, is represented by private external loans and holdings of external bonded debt, and by multilateral lending, within which I distinguish IMF and non-IMF loans. ${ }^{15}$ Liability dollarization, in turn, is computed as the ratio between total foreign currency liabilities (where onshore dollar loans are proxied by onshore dollar deposits) over total liabilities (where, for consistency, onshore loans are proxied by onshore deposits).

Table 1 provides a first glance at these different categories. For comparison, the table includes emerging countries for which data on all categories are available (and excludes offshore centers where FD is likely to be driven by factors of a different nature). Two things are worth noting in the table. First, the degree of exposure have remained

${ }^{14}$ This focus on external debt implicitely presumes a link between bondholders' residence and debt jurisdiction that is, at best, imperfect.

${ }_{15}$ The latter distinction is important. As already noted, the approach to IFI participation in the dedollarization effort discussed in this paper does not apply to an institution like the IMF that is not funded in the market. 
relatively stable in recent years. Second, the median exposure to non-IMF IFI lending, which has increased slightly, exhibits levels comparable to that of external loans and is higher than that associated with domestic dollarization and external bonded debt (the focus of much of the empirical FD literature). Based on median values, it accounts for more that one fourth of total external dollarization and one fifth of total dollarization. These numbers by themselves indicate that a strategy aimed at reducing FD cannot ignore the role of IFIs.

\section{III.Offshorization and financial dollarization}

One aspect of the FD debate often overlooked by the literature is the interaction between country risk and the degree dollarization for non-investment grade economies. Trivially, if country risk drives domestic savings abroad where no local currency assets are available, higher country risk would be, other things equal, associated with higher total dollarization ratios (inclusive of offshore deposits), leading to a smaller volume of peso loanable funds. In turn, this deficit would be partially compensated by a greater dependence on foreign dollar borrowing (to the extent that it insulates investors from country risk better than domestic assets) and, ultimately, on IFI lending. This section presents a stylized analytical example to illustrate this intuition, and tests its empirical implications in the data.

\section{a. An analytical example}

The link between country risk, offshorization and dollarization can be illustrated by a simple example that extends portfolio approach used in Ize and Levy Yeyati (2003).

Consider the following scenario. A continuum of measure $S$ of risk-averse resident investors endowed with a unit of cash, can invest in four alternative assets: peso and dollar debt issued in a non-investment grade emerging economy (the home economy) and peso and dollar debt issued in an investment grade developed economy (the foreign 
economy). Denoting the portfolio shares by $x^{F}, x^{H}, x^{C F}$, and $x^{C H}$, where the superscripts $F, H, C F$ and $C H$ refer to dollar and peso assets in the home and the foreign economies, respectively, the real returns on each asset as measured by the resident investor would be given by:

$$
\begin{gathered}
r^{H}=E\left(r^{H}\right)-\mu_{\pi}-\mu_{c} \\
r^{F}=E\left(r^{F}\right)+\mu_{s}-\mu_{c} \\
r^{C F}=E\left(r^{C F}\right)+\mu_{s} \\
r^{C H}=E\left(r^{C H}\right)-\mu_{\pi}
\end{gathered}
$$

where and $\mu_{\pi}, \mu_{s}$ and $\mu_{c}$ are zero-mean disturbances to the local inflation rate, the real (peso-dollar) exchange rate, and the home country's sovereign risk, assumed to be distributed with variance-covariance matrix $\left[S_{x y}\right]$, with $S_{c s}=S_{c \pi}=0 .{ }^{16}$ In turn, $E\left(r^{j}\right)$ denotes the expected real return on the assets.

On the other hand, a continuum of measure $L$ of risk-neutral local borrowers have access to a production technology with known unit real returns (which, for simplicity, I assume that exceed unit borrowing costs) that can be financed from three sources: domestic peso and dollar debt, and foreign borrowing (whose share in the liability portfolio is denoted by $x^{C}$ ). The first two instruments are identical to those available to investors. Offshore lending, on the other hand, can be interpreted at least in two ways: as foreign lending by private investors (under the assumption that offshorization indeed provides limited protection from country-specific risk), or by IFIs (under the assumption that the preferred creditor status eliminates default risk). For the moment, it suffices to assume that the access to this source entails an additional unit cost $\phi(X)$, with $\phi^{\prime}(X)>0$, where $X=x^{C} L{ }^{17}$

\footnotetext{
${ }^{16}$ The qualitative results are not driven by these simplifying assumptions. In Appendix II, I present the solution for the case in which country and real exchange rate risk are not independent.

${ }^{17}$ If the source is private foreign investment, these costs would capture the fact that foreign contracts, while perceived as providing better protection from confiscation risk than domestic contracts, are still subject to sovereign default. Alternatively, if the source is IFI lending, the costs may reflect the upward sloping cherge scale typically applied to non-concessional multilateral loans, as well as costs associated with the process of requesting the loan and complying with the attached conditionalities.
} 
Then, interest rate arbitrage implies that

$$
E\left(r^{H}\right)=E\left(r^{F}\right)=E\left(r^{C}\right)+\phi,
$$

Assume further that investors maximize risk-adjusted real return measured in units of the local consumption basket:

$$
\max _{x^{j}} U=E(r)-\frac{c}{2} \operatorname{Var}(r)
$$

where

$$
\begin{gathered}
x^{j} \geq 0, \\
r=\sum_{j} x^{j} r^{j}
\end{gathered}
$$

It can be shown (see Appendix II) that any solution to the portfolio problem can be characterized by the following dollarization and offshorization ratios:

$$
\lambda \equiv x^{F}+x^{C F}=\lambda_{u}-\frac{1}{c V} E\left(r^{H}-r^{F}\right)
$$

and

$$
\gamma \equiv x^{C F}+x^{C H}=1-\frac{1}{c S_{c c}} E\left(r^{F}-r^{C F}\right)
$$

where

$$
V \equiv \operatorname{Var}\left(\mu_{\pi}+\mu_{s}\right)=S_{\pi \pi}+S_{s s}+2 S_{\pi s}
$$

and

$$
\lambda_{u}=\frac{\left(S_{\pi \pi}+S_{\pi s}\right)}{V}
$$

is the dollarization share in the absence of real return differentials (henceforth, the underlying dollarization ratio). Note that, in this simplified setup where domestic interest rate differentials are ruled out by arbitrage, $\lambda=\lambda_{u}$.

Equations (3) and (4) characterize a continuum of portfolios that maximize the investors' utility. While the availability of offshore peso assets has no incidence on the dollarization ratio if $\gamma<\lambda_{v}$, it does so in the case in which $\gamma \geq \lambda_{v}$, where the excess of offshore assets over the desired dollar assets can only be held in pesos (that is $x^{C H} \geq \gamma$ - 
$\lambda_{v}$,). Therefore, if offshore peso assets were not available, dollarization would be driven entirely by offshorization, as the latter could never be below the dollarization ratio.

More generally, it can be shown that, if the optimal offshorization ratio exceeds the desired dollarization ratio, in the absence of country risk-free peso assets, the new dollarization ratio (identified by the lower bar) is given by (see Appendix II):

$$
\gamma>\underline{\gamma}=\underline{\lambda}=\frac{S_{\pi \pi}+S_{\pi s}+S_{c c}}{V+S_{c c}}-\frac{1}{c\left(V+S_{c c}\right)} E\left(r^{H}-r^{C F}\right)>\lambda_{u} .
$$

The intuition is straightforward: if peso assets are not available abroad, capital flight translates directly into an increase in the dollarization ratio. ${ }^{18}$ The difference $\underline{\lambda}-\lambda_{u}$, which is increasing in country risk, is solely due to the absence of a country risk-free asset in the local currency.

The previous analysis can be readily extended to the case of CPI-indexed domestic assets, as perfect indexation could be expressed, in terms of this example, as $\mu_{\pi}=0$. Therefore, if domestic peso assets are indexed to the local CPI, the dollarization ratio from (7) would be equal to $\frac{S_{c c}}{S_{c c}+S_{s s}}$, and would be entirely driven by country risk. In other words, country risk sets a floor to the extent to which a non-investment grade country can reduce FD either through monetary policy (reducing inflation volatility and the exchange rate pass-through) or through CPI indexation.

How does the offshorization of domestic savings impact on the currency composition of resident liabilities? To answer this question, first note that the domestic balance of funds requires that

$$
L(1-x)=(1-\gamma) S
$$

and, for the peso market,

$$
\left(1-\lambda^{B}\right) L=(1-\lambda) S
$$

where $\lambda^{B}$ denotes the borrower's dollarization ratio.

\footnotetext{
${ }^{18}$ Note that this is also the dollarization ratio that would obtain should local dollar deposits be banned, leaving offshorization as the only option to dollarize savings.
} 
If offshorization were not binding, an increase in country risk would not alter the amount of available peso funds, and the resulting decline of domestic funds would be perfectly offset by an increase in foreign borrowing $x^{C} .19$

However, when the offshorization ratio is binding, the supply of peso funds is automatically determined by the offshorization ratio as, from (8) and (9), we obtain:

$$
\left(1-\lambda^{B}\right) L=(1-\gamma) S=L(1-x)
$$

or $\lambda^{B}=x$. In this case, the borrower has effectively two options: domestic peso loans (limited by the domestic supply of funds) and dollarized foreign borrowing. As country risk mounts, the cost of the former relative to the latter increases, raising the liability dollarization ratio (which is now due entirely to foreign borrowing). The associated increase in peso interest rates offsets $r^{H}$, on the other hand, partially offsets the offshorization (and dollarization) of domestic peso savings as a response to higher country risk. ${ }^{20}$

It is immediate to see that the presence of country-risk free offshore assets restores (9), as the borrower can now meet his financing needs by borrowing pesos abroad (at the peso risk-free rate plus the transaction cost $\phi$ ), decoupling the choice of currency and location. In particular, increases in $x$ as a result of higher country risk need no longer have an impact on $\lambda^{B}$.

In sum, high country risk is associated with a high offshorization ratio and, if the latter is sufficiently large, with a smaller supply of peso loanable funds. In turn, to the extent that foreign borrowing is relatively immune to country risk, higher country risk would lead to a larger share of foreign borrowing and, in the absence of risk-free peso assets, higher dollarization ratios.

\footnotetext{
${ }^{19}$ In the more general case of diminishing marginal returns to investment, to the extent that the demand for loans respond to the higher financing costs due to the increase in country risk, the decline in total borrowing could weaken the demand for peso loans and put downward pressure on the peso-dollar differential, increasing asset dollarization $\lambda$ while and reducing liability dollarization $\lambda^{B}$.

${ }^{20}$ It can be readily seen that $\lambda^{B}=1-(1-\gamma)(S / L)$, so that $\partial \gamma / \partial S_{c c}>0$ implies that $\partial \lambda^{B} / \partial S_{c c}>0$.
} 


\section{Are non-residents different?}

An argument repeatedly made in the literature stresses that hedging considerations indicate that resident investors are likely to exhibit smaller dollarization ratios than nonresident investors. ${ }^{21}$ The previous example helps illustrate the point.

First, note that, using $\mu_{\mathrm{s}} \approx \mu_{e}-\mu_{\pi}$, where $\mu_{e}$ denotes nominal exchange rate shocks, underlying dollarization simplifies to

$$
\lambda_{u}=\frac{S_{\pi e}}{S_{e e}}
$$

the coefficient of a simple regression of the inflation rate on the nominal exchange rate, that is, a crude measure of the exchange rate pass through.

Starting from (11), and exploiting the symmetry of this setup, it is easy to verify that, in a stylized two-country world, the degree of underlying "pesification" (that is, the share of foreign currency assets over total assets) of foreign residents would be equal to:

$$
\lambda_{u}^{*}=\frac{S_{\pi^{*} e^{*}}}{S_{e^{*} e^{*}}}
$$

where $e^{*}$ denotes the dollar-peso exchange rate, and $\pi^{*}$ the rate of inflation in the foreign country.

It follows that the underlying demand for peso assets from residents and non-residents is highly asymmetric. On the one hand, non-resident demand for assets denominated in emerging currencies is proportional to the pass-through coefficient of changes in the exchange rate vis à vis the emerging currency, which is unlikely to be statistically different from zero for developed economies (and for most emerging economies). On the other, for any pair of countries with comparable pass-through coefficients, any coefficient below 50\% would imply that the demand for local currency assets from residents should

\footnotetext{
${ }^{21}$ See Thomas (1985) for an early reference.
} 
exceed that from non-residents. In both cases, the asymmetry deepens as inflation volatility (and the pass-through coefficient) in the emerging economy declines and, by extension, when the peso assets are indexed to the local inflation rate.

This example certainly oversimplifies the portfolio choice of the representative resident and non-resident investors. In particular, it abstracts from cross-border transaction costs that in practice introduces a source of investor heterogeneity that helps explain the permanence of a captive pool of domestic dollar funds from small investors in the midst of a sovereign debt crisis.

However, the exercise provides a valid intuition in relation to two points that are critically important to assess the role of IFIs in the development of a market for peso assets: i) the incidence that country risk may have (through the offshorization of domestic savings) in determining FD in non-investment grade countries; and ii) the fact that local currency assets are likely to look more appealing to resident investors than to foreigners, particularly in those countries where inflation is relatively stable.

\section{b. Offshorization and dollarization in the data}

The previous analysis offers a number of empirical implications. First, in the absence of risk-free instruments in exotic currencies, non-investment grade countries may see a substantial portion of their domestic savings dollarized simply as a result of the flight of capital to safer investments abroad. In turn, this capital flight, inasmuch as it reduces the volume of domestic loanable funds, increases both financing costs and the country's dependence on external borrowing, to the extent that the latter is perceived as less exposed to country-specific credit risk.

Regarding the last point, some observers have argued that offshore assets (and, in particular, external debt) are free from government interference with the laws governing the financial contracts or, alternatively, with the local judiciary system in charge of 
enforcing them. ${ }^{22}$ From this perspective, as country risk increases, we should see the balance between domestic and external debt tilt towards the latter. However, while a foreign jurisdiction may certainly protect the debt holder from direct government acts, cases in which debt restructuring discriminates in favor of domestic assets are not unusual, as shown by the differential treatment typically assigned to domestic bank deposits during default episodes as well as recent cases of selective default. ${ }^{23}$

At any rate, inasmuch as offshorization remains only a partial protection towards country risk, one would expect that a more limited access to domestic finance would make non-investment grade countries more dependent on IFIs lending. ${ }^{24}$ This section explores whether this intuition is consistent with the empirical evidence.

To do that, I distinguish between onshore dollarization ratio (computed as onshore dollar deposits over total onshore deposits), and deposit dollarization $\left(\lambda_{u}\right)$, computed as the share of dollar on total deposits including resident deposits abroad. The second variable, while less frequent in the literature, is nonetheless a more accurate measure of the degree of dollarization of residents' portfolios as depicted in the analytical example, and the one that more clearly reflects the incidence of both underlying dollarization and offshorization, where the latter is measured as the ratio between offshore and total resident deposits. The onshore supply of loanable funds is proxied by the ratio of onshore deposits over GDP. ${ }^{25}$ I look at two sources of external dollarization, namely, non-official (private) lending (which groups external loans and external bonded debt), and official lending (where I distinguish between IMF and non-IMF lending). Liability dollarization, in turn, is computed as the ratio between total foreign currency liabilities over total liabilities, where currency composition of onshore loans is proxied by that of onshore deposits. Finally, country risk is measured as the stripped spread of sovereign debt over

\footnotetext{
${ }^{22}$ See, e.g., De la Torre and Schmukler (2003).

${ }^{23}$ The recent Argentina default is a clear example in which domestic creditors received a more benign treatment.

${ }^{24}$ Note that this does not refer to higher IMF assistance during crisis episodes, but rather to a more permanent dependence on lending from multilateral development banks.

${ }^{25}$ I chose onshore deposits instead of M2 or domestic credit to be consistent with the way the offshorization ratio is computed. However, all three variables are highly correlated and yield virtually identical results.
} 
comparable US Treasuries, as captured in the EMBI Global Index compiled by J. P. Morgan.

Table 2 provides a first glance at the links between country risk, the location and currency composition of resident savings, and the different sources of external dollarization, by looking at the correlation of their period averages. ${ }^{26}$

The first things to note from the table are the association of country risk with a smaller volume of onshore loanable funds and a greater offshorization ratio, on the one hand, and the high and positive correlation between the latter and total deposit dollarization (and, in turn, between deposit dollarization and country risk), on the other. Both findings are consistent with the implications of the previous model.

Regarding the sources of external liability dollarization, the table reveals no clear link between country risk and non-official external finance, suggesting that, while offshore debt may provide some protection against country risk (hence, the weaker negative link between these two variables), it does not offset the decline in domestic funds. This decline is ultimately compensated by a larger dependence on IFI lending, as reflected in a larger ratio over GDP as well as in a larger IFI-to-total external credit ratio.

These links are explored more in detail in Table 3. As the table shows, risky countries are associated with fewer onshore deposits (columns 1-3) and greater deposit offshorization (columns 4-6), even after controlling for onshore dollarization, and for the presence of restrictions on dollar deposits that may potentially bias residents towards offshore assets if capital flight were motivated by currency risk (interestingly, restrictions appear to be positively related with onshore deposits and negatively related with offshorization).

\footnotetext{
${ }^{26}$ Averaging periods vary by country, as they correspond to those for which the country risk measure is available.
} 
Thus, country risk appears to be an additional important determinant underlying a weak demand for peso assets in non-investment grade countries. However, unlike in the standard portfolio approach, in this case dollarization is simply a by-product of the lack of investment-grade peso assets. This is confirmed by the fact that deposit dollarization, even after controlling for country risk and underlying dollarization (computed from equation (6) based on monthly inflation and real exchange rate data), is still positively associated with the deposit offshorization ratio (columns 7 and 8). This result holds for the larger sample obtained by dropping the country risk index (column 9), and in a dynamic setting with country fixed effects (columns 10 and 11).

Table 4, in turn, shows that the offshorization ratio is associated with greater IFI dependence. This positive link is verified both cross-section and over time, for either IMF or non-IMF official lending. This contrasts with the lack of a significant link with other sources of external credit reported in Table 5 (columns 1 and 2). Similarly, no link is found when total external long-term liabilities are used as a proxy for foreign currency external debt (columns 3 and 4). ${ }^{27}$ Finally, the table shows how liability dollarization is positively correlated with deposit offshorization (columns 5-8), in line with a higher dependence on IFI lending.

In sum, the evidence is consistent with the hypothesis that, in the absence of risk-free instruments in exotic currencies, non-investment grade countries may see a substantial portion of their domestic savings dollarized simply as a result of the flight of capital to safer investments abroad. In turn, this capital flight, inasmuch as it reduces the volume of domestic loanable funds, increases the country's dependence on dollarized IFIs lending, shifting the currency liability composition towards the foreign currency as a consequence.

\footnotetext{
${ }^{27}$ These data is available from the World Bank's GDF for a larger sample and a longer period. The implicit assumption that all external debt issued by non-industrial countries is denominated in foreign currency seems to be a reasonable approximation.
} 


\section{Financial dedollarization and the IFIs}

As the previous discussion highlights, IFIs tend to substitute domestic sources of finance in non-investment grade countries. Crucially, the role of IFIs in the context of a narrow domestic market does not necessarily entail, as sometimes argued, a significant subsidy to emerging economies. Indeed, recent work have revealed that the subsidy component in IMF non-concessional lending to emerging economies is virtually null (Jeanne and Zettelmeyer, 2001), as follows from the absence of default episodes in the past - a result that would also apply to other IFIs blessed with a similar preferred creditor status.

Indeed, a key characteristic of IFIs is that, unlike private investors, and for reasons that exceed the scope of this paper, they exhibit a surprisingly good repayment record. ${ }^{28}$ Thus, at the risk of oversimplifying, one can think of IFIs as contributing to a "sovereign risk transformation." Specifically, they can be seen as matching the supply of private funds in search of investment grade securities, and the demand of funds by noninvestment grade economies. By intermediating between the two, the IFIs exploit their superior enforcing capabilities to channel these funds into lending that, through their intervention, becomes virtually risk-free.

It is only natural, then, to exploit this advantage to foster the supply of local currency funds that are lost due to sovereign risk considerations. This does not requires the extension of additional lending by the IFIs, but rather the issuance of investment grade paper to meet the demand for risk-free local currency securities, and the use of the proceeds to convert part of the outstanding stock of IFI loans so as to keep a balanced currency position.

As noted in the introduction, while schemes along these lines have already been proposed and have been the subject of discussion by economists and IFI staff in recent

\footnotetext{
${ }^{28}$ The reasons why IFIs can successfully enforce their preferred creditor status are certainly a fruitful research topic that exceeds the scope of this paper.
} 
years, little, if any, progress has been made so far in that direction. This section reviews the existing facilities offered by IFIs to their clients to hedge their currency exposure, and the alternative proposals related to the dedollarization of external liabilities. In particular, it describes a scheme oriented to meet the demand for local-currency investment-grade securities by residents along the lines discussed in the previous section, addressing in the process the main criticism faced by old and new initiatives of this type.

\section{What's in the menu?}

While the concerns related with currency mismatches has been increasingly acknowledged by IFIs, their supply of hedging instruments available is still rather limited. The World Bank (WB), for example, offers the option to convert outstanding loan obligations (or to request a swap of its foreign currency obligation) into local currency. Since WB loans are funded in the foreign currency, the transaction requires that the Bank arranges a local-foreign currency swap with a third financial institution to transfer the currency exposure. ${ }^{29}$

These local currency products are not without benefits, particularly for noninvestment grade clients that would be otherwise unable to access long-dated currency swaps directly in the capital markets. However, they are typically limited in volume, shorter than the loan they are intended to hedge, and granted on a case-by-case basis subject to the existence of a liquid swap market. ${ }^{30}$

More importantly, rather than expanding the pool of local currency funds, they tap on existing swap markets. Thus, while they are likely to benefit local borrowers through longer duration and reduced transaction (e.g., collateral) costs, they are also likely to

\footnotetext{
29 For details, see the brochure on Local Currency Financial Products posted on www.worldbank.org/fps/hedging.htm. Currency swaps are also offered by the Inter-American Development Bank (IDB).

${ }^{30}$ The emerging markets that, according to the World Bank, satisfied this condition by end-2003 included Brazil, Chile, Colombia, the Czech Republic, Hungary, India, Indonesia, Mexico, Malaysia, Philipines, Poland, the Slovak Republic, South Africa, South Korea and Thailand. Of these, only Colombia, India, Indonesia and the Philipines are non-investment grade countries.
} 
crowd out the available supply of hedging instruments. At any rate, and possibly because of their limited benefits, these relatively new products have not been in high demand. ${ }^{31}$

The WB have also launched a few issues in investment-grade exotic currencies. ${ }^{32}$ The modality is not uniform. For example, the February 2000 3-year euronote in Mexican pesos was issued abroad and was largely placed among American investors, on the back of strong external demand shortly after rating agencies announced that they were considering an upgrade of the country's debt to investment grade. On the other hand, the May 2000 Chilean CPI-indexed peso 5-year euronote was distributed mainly among domestic institutional investors, who purchase about $75 \%$ of the total issue.

While these issues are not without positive spillovers for the development of local currency markets, their value added in the context of a dedollarization agenda is questionable, as the risk transformation role emphasized in this paper is bound to be less valuable for economies that already enjoy investment-grade status. By contrast, the analysis in the previous section suggests that the best use of the IFIs' advantage entails external issues (to minimize the crowding out of available domestic funds) in noninvestment grade countries (unable to attract domestic investors in search of low-risk assets).

A move in this direction was the March 2004 Colombian CPI-indexed bond, issued and placed domestically by the WB within domestic institutional investors. While it still has the potential to crowd out existing (captive) demand for peso assets, the bond was nonetheless welcome by the government as a way to satisfy the appetite for risk-free long assets in the local currency from the growing private pension system, which would otherwise have to be met by foreign assets. ${ }^{33}$ Closer to the scheme proposed here was the May 11, 2004 eurobond in Brazilian reais issued by the Inter-American Development

\footnotetext{
${ }^{31}$ As of April 2004, only three countries had sign the Master Derivatives Agreement required by the WB to request a currency swap.

32 A list of recent World Bank issues can be found in http://www.worldbank.org/debtsecurities/recent issues.htm.

${ }^{33}$ The same would apply to domestic issues in investment-grade Chile, where a sustained fiscal surplus leaves little room for the issuance of long-dated sovereign paper.
} 
Bank (IDB), which included selling restrictions in Brazil to avoid crowding out domestic resources. ${ }^{34}$

These issues certainly reflect a welcome shift in the funding strategies of some IFIs. However, contrary to what one would be led to believe, they have been entirely motivated by the search of lower funding costs. Indeed, rather than used to convert outstanding loans into the same exotic currencies, their proceeds have been immediately swapped into dollars. Thus, for all the merit that these efforts may have, their effective impact in terms of dedollarizing the liabilities of emerging economies has been virtually null.

\section{What has been proposed?}

Most of the discussion about the type of peso instrument best fit to substitute current dollar assets while maximizing its hedging potential has centered around CPI indexation, an avenue that proved to be successful in containing and undoing FD in Chile and Israel, particularly when it comes to longer financial contracts. The local CPI, the most obvious candidate index for domestic residents, has been confronted with several alternatives in the same spirit, particularly when targeting foreign investors.

In general, indexation of dollar-denominated instruments to a price closely correlated with the debtor's income could in principle attain what could be labeled synthetic dedollarization, decoupling the real cash flows of the asset (measured in units of the debtor's income) from the evolution of the real exchange rate. While in practice these instruments may be more opaque for the average investor than a plain CPI-indexed local currency bond (and, in turn, more difficult to market), they may be free from moral hazard and thus potentially attractive for sophisticated investors. Crucial in this regard is the exogeneity of the index of choice. ${ }^{35}$

\footnotetext{
${ }^{34}$ This was just the second international issue in a Latin American currency by an IFI. The first one, in April 2004, was a global bond denominated in Mexican pesos. To my knowledege, no other multilateral development bank has issued debt in non-investment grade currencies.

${ }^{35}$ Indexation to a tax revenue index, for example, offers no such advantage.
} 
Among the latter, two alternatives stand out: a GDP index, and a commodity index. ${ }^{36}$ Both are similar in nature, being equivalent to a plain vanilla bond plus a short position in the commodity or the issuing country's GDP, and both are subject to the country's sovereign risk. While commodities are more easily priced and hedged due to the existence of derivative markets, their use is bound to be limited to commodity exporters, and to the extent these exports correlate with the country's income. Moreover, much in the same way as for the currency swap discussed above, it is not clear how such indexation improves upon a short hedge purchased directly by the issuer in the derivative markets (although access to these markets may be more costly for non-investment grade issuers). On the other hand, while GDP indexation may be more suitable to smooth out countercyclical variations in debt-to-GDP ratios and borrowing costs, it is difficult to see how GDP risk can be stripped and hedged by potential investors, particularly in the absence of a market for GDP indexes. ${ }^{37}$

The same caveats apply in principle to CPI-indexation as a way of luring foreign investors. Eichengreen and Hausmann (2002) stress the attractiveness of a basket of CPIindexed exotic currencies for non-residents. Moreover, they specifically propose that IFIs issue debt in these currencies to fund their own lending to emerging economies and provide the needed liquidity for the index. This requires matching not only the demand and supply of funds in each currency but also across currencies to allow for the needed diversification strategy. As such, it involves a non-trivial coordination effort. Furthermore, while speculative non-resident demand for specific currencies perceived as undervalued is not unlikely (as the IDB issue in Brazilian reais attests), interest from

\footnotetext{
${ }^{36}$ See Borensztein and Mauro (2002) on GDP-indexed bonds, and Caballero and Panageas (2003) on copper-indexed debt for the case of Chile.

37 To my knowledge, among emergng economies, only Bulgaria has issued a GDP-indexed bond (albeit with a call clause that eliminates the upside from indexation). The bond was originally placed among institutional investors and has hardly traded since. At the time of this writing, September 30, the Argentine government is considering the use of GDP indexation in its forthcoming debt exchange offer.
} 
long-run international investors seeking a diversified portfolio with stable returns is more difficult to envisage. ${ }^{38}$

\section{IFIs and the intermediation of resident savings}

Once we shift the focus away from international investors to target the demand from residents, the use of CPI indexation presents important advantages, including the fact that it can be measured at daily frequencies (improving the accuracy of the indexation) by an autonomous agency (ensuring that the index is free from government manipulation). More importantly, unlike other indexes, the CPI enjoys a demand arising from the hedging properties highlighted in the previous section. As such, it is a natural choice to jump start the dedollarization process with the help of an investment grade issuer (the IFIs) that decouples sovereign and currency risk, to attract domestic investors willing to invest in their own currency at a reasonable level of credit risk. ${ }^{39}$

Resorting directly to the domestic market, however, may have economic (and political) drawbacks, as it crowds out already available local-currency funds by inducing a shift from high-risk government and corporate domestic debt to investment-grade IFI paper. In that case, while the new issue may contribute to extend the market for local currency securities onshore by bringing in new investors previously reluctant to assume country risk, it is likely to increase the cost of funds domestically, inducing the government to borrow abroad, with only a minor change in the overall composition of government liabilities. Thus, in order to maximize the beneficial composition effect, the new debt should be issued in international markets, to cater investors the seek stable returns in units of the local consumption basket, but are reluctant to take on sovereign risk.

\footnotetext{
${ }^{38}$ Interestingly, Borensztein and Mauro also highlight the appeal of GDP-indexed bonds for a diversified international investor. To their credit, emerging market debt as an asset class may have looked as distant prior to the Brady plan as GDP-indexed or CPI-indexed bonds look today.

${ }_{39}$ Risk decoupling is at the heart of the Eichengreen-Hausmann proposal. However, in that context, currency risk is tolerated to the extent that it can be diversifed away in a basket of exotic currencies. In the current version, by contrast, CPI indexation eliminates currency risk from the resident's stanpoint, so that no currency diversification is required.
} 
Both the literature and the recent experiences point at institutional investors as the natural target of the first issues. Consider, for example, the case of pension funds. The advantages of the CPI as the benchmark unit of account are apparent: By acquiring a credit risk-free asset denominated in units of the consumption basket, they fulfill their role as guarantors of a stable stream of income after retirement while avoiding countryspecific credit risk. ${ }^{40}$ Indeed, pension funds are typically allowed to invest a fraction of their portfolio in investment-grade foreign assets (see Table 6), a fraction that has been growing, particularly since the Argentine debacle sounded the alarm on excessive exposure to sovereign risk. Thus, while the government borrows from IFIs, a share of residents' retirement savings is being invested abroad in triple A paper such as that issued by IFIs to fund their loans. IFIs can readily channel these funds back into the domestic economy by selling to the pension funds CPI-indexed bonds to finance loans denominated in the same index. ${ }^{41}$

The demand for a long-dated investment-grade local-currency paper that may come from institutional investors, as well as resident savings abroad, may reach important levels, as shown in Table 7, which compares stocks of pension funds assets, resident deposits abroad, and outstanding IFI loans, for emerging economies that have recently privatized their social security system. ${ }^{42}$

As noted, a few successful IFI issues in exotics currencies already revealed the existence of a demand for these securities. In this context, the redollarization of their proceeds is particularly puzzling, and at odds with the concerns about FD repeatedly endorsed by IFI officials and publications. Given the already high exposure of these

\footnotetext{
${ }^{40}$ Pension fund regulation should acknowledge this explicitely in order to align the incentives of pension fund managers along these lines. See Carriquiry and Gruss (2004) for a discussion of the case of Uruguay.

${ }^{41}$ An alternative approach that has been the subject of informal discussion among IFI staff is the use of IFI guarantees to local currency debt to reduce the credit risk of non-investment grade issues in exotic currencies. Halfway between a risk-free IFI bond and risky emerging market paper, this combination (if guarantees are capped in dollars) would entail for the IFIs similar risks as those associated with existing guarantees to dollar bonds.

${ }_{42}$ The previous analyses does not deny the existence of non-resident demand for exotic currencies. However, while anecdotal evidence indicates that this demand do exist, it is likely to be driven by shortterm speculative appreciation games rather than by the long-run diversified investors needed to build the market.
} 
institutions with many of their clients, it is easy to see how the swap with a third financial institutions that followed the issuance of these bonds could have been done, alternatively, directly with the client, partially dedollarizing outstanding obligations. While the cash flows of the bond would typically be different from that of the loan, the swap markets provide sufficient flexibility to match both schedules with little, if any, additional transaction costs. On the other hand, the settlement currency of both streams of cash flows would be immaterial in this case. In particular, even if the currency of denomination of the original loan is preserved, his obligation would be indexed to the local currency (or the local CPI), eliminating any currency exposure -an argument also valid for new lending. Moreover, and for the same reason, there is no obvious rationale to limit the currency conversion to the local expenditure component of the loan (as is currently the case for existing local currency products). Indeed, an appropriate hedging strategy would need to match the currency composition of liabilities with that of future earnings (as opposed to past expenses). In sum, there seems to be no obvious obstacle to onlend the funds obtained from local currency issues to emerging market clients.

\section{Addressing the skeptics}

Besides the mixed reviews received by markets participants, the proposals to dedollarize IFI lending have faced criticism from within IFI circles. The present analysis would not be complete without a brief discussion of some of them.

Rajan (2004) summarizes two of the main arguments. First, he points out that a portfolio approach to FD should take into account the correlation between financial returns and non-financial income. More precisely, to the extent that economic activity is negatively correlated the real exchange rate, local savers would demand lower returns on dollar assets that are used as a hedge against economic downturns. In principle, however, this preference should not induce FD, as local debtors would be willing to pay the higher returns demanded on peso assets to hedge their income stream. 
The second argument is more relevant to our discussion: In the presence of myopic behavior, one would expect emerging market borrowers to exploit the lower dollar borrowing costs in good times, disregarding the contingent cost of the associated exposure -likely to be borne by others. ${ }^{43}$ Note that, while the peso interest rate charged by IFIs would be below that demanded by private lenders (due to the lower credit risk), the conversion of outstanding IFI loans to the local currency would not save debtors the currency risk premium that induced dollarization in the first place. In other words, if FD were the result of asymmetric risk pricing, rather than lack of investment grade local currency assets as argued here, opportunistic debtors would turn down the offer to insure against future balance sheet effects at a fair price. If so, the proposed dedollarization strategy, rather than suffering from the lack of investor interest, may be condemned by the indifference of the very debtors that it is intended to relieve.

This agency argument looks a bit overdone in light of recent dedollarization efforts in emerging economies. ${ }^{44}$ Nonetheless, taking the argument at face value, one can only conclude that it would be in the interest of the IFIs to correct this imperfection by including dedollarization within the standard conditionality set, rather than offer misleadingly cheap dollar lending to perpetuate this perverse cycle. Ultimately, agency problems provide yet another reason for IFIs to adopt a more proactive stance.

\section{Final remarks}

This paper tried to convey a simple message: to the extent that country risk induces financial dollarization through the offshorization of domestic savings -as the analysis and the evidence presented here seem to indicate-, IFIs can exploit their superior enforcement

\footnotetext{
${ }^{43}$ Variations on this argument have been examined in the literature in relation to market imperfections such as implicit guarantees (Bumside at el., 2001), or currency-blind regulation (Broda and Levy Yeyati, 2003) that are conducive to excessive dollarization.

${ }^{44}$ Examples include, among others, the gradual dedollarization of public debt in post-Tequila Mexico and, more recently, Brazil; the revision of the prudential framework as well as the introduction of CPI-indexed assets in Uruguay; and the imposition of quantitative restrictions on the on-lending of onshore dollar deposits in Argentina after the demise of the currency board.
} 
ability to intermediate these savings back into the domestic economy without increasing financial dollarization.

For IFIs, this would not require expanding credit, transferring resources or incurring currency risk. Rather, it would involve issuing local currency bonds and using the proceeds to gradually convert current loans into (or refinance maturing loans in) the local currency. Far from a final solution to the dollarization problem, this initiative represents a feasible starting point for the much needed development of local currency markets. While successful issues of IFI debt in exotic currencies are an encouraging first step, a coordinated effort is still needed to convince governments and the IFIs of the benefits of using the proceeds to dedollarization multilateral lending.

This paper did not argue that the scheme described above is a sufficient condition to reduce FD in emerging economies. Needless to say, the demand for local currency assets (and, more generally, the achievement of financial stability) would be contingent on the implementation of responsible economic policies consistently over time. However, while good policies are by definition a good advice, they are not always sufficient to collect the full reward. It is along that margin where the IFIs can make a contribution. 


\section{References}

Aghion P., Bolton P. and Dewatripont, M., 2000. Contagious Bank Failures in a Free Banking System, European Economic Review.

Berganza, J. C., R. Chang and A. García Herrero (2003). Working Paper 306, Bank of Spain.

Berganza, J. C. and A. García Herrero (2004). What Makes Balance Sheet Effects Detrimental for the Country Risk Premium? Mimeo. Bank of Spain.

Bordo, M., Ch. Meissner and A. Redish (2002). How “Original Sin” was Overcome: The Evolution of External Debt Denominated in Domestic Currencies in the United States and the British Dominions 1800-2000. Mimeo.

Borensztein, E. and P. Mauro (2002). Reviving the Case for GDP-Indexed Bonds. IMF Policy Discussion Paper 02/10.

Broda, Ch. and E. Levy-Yeyati (2003). Endogenous Deposit Dollarization. Federal Reserve Bank of New York Staff Papers 160.

Burnside, C., M. Eichenbaum, S. Rebelo, (2001). Hedging and Financial Fragility in Fixed Exchange Rate Regimes. European Economic Review 45 (7).

Caballero, R. and S. Panageas (2003). Hedging Sudden Stops and Precautionary Recessions: A Quantitative Approach. Mimeo, MIT.

Calvo, Guillermo and Pablo Guidotti (1989). Credibility and nominal debt: exploring the role of maturity in managing inflation. IMF Working Paper 89/73. 
Calvo, G., A. Izquierdo and L. F. Mejía (2004). On the Empirics of Sudden Stops: The Relevance of Balance-Sheet Effects. Mimeo, Inter-American Development Bank.

Carriquiry, F. and B. Gruss (2004). Dolarización y Fragilidad Financiera del Sistema de Pensiones: El Caso de Uruguay, forthcoming, Revista de Economía, Central Bank of Uruguay.

Céspedes, L., R. Chang and A. Velasco (2000). Balance Sheet Effects and Exchange Rate Policy. NBER Working Paper 7840.

Claessens, S., D. Klingebiel and S. Schmukler (2003). Government Bonds in Domestic and Foreign Currency: The Role of Macroeconomics and Institutional Factors. Mimeo, The World Bank.

De la Torre, A., E. Levy-Yeyati and S. Schmukler (2003). Beyond the Bipolar View: The Rise and Fall of Argentina's Currency Broad. Economía, vol. 5 (2).

De la Torre, A. and S. Schmukler (2003). Financial Contracting in Emerging Economies. Mimeo, The World Bank.

De Nicoló, G., P. Honohan, and A. Ize (2003). Dollarization of the Banking System: Good or Bad? Mimeo, IMF.

Domac, I. and M. S. Martínez Pería (2000). Banking Crises and Exchange Rate Regimes: Is There a Link? Journal of International Economics, forthcoming.

Eichengreen, B. and R. Hausmann (2002). Original Sin: the Road to Redemption, forthcoming in Eichengreen and R. Hausmann (eds.) Debt Denomination and Financial Instability in Emerging-Market Economies, Chicago: University of Chicago Press. 
Eichengreen, B., R. Hausmann, and U. Panizza (2003). Currency Mismatches, Debt Intolerance and Original Sin: Why They are Not the Same and Why it Matters, NBER Working Paper No. 10036.

Goldstein, M., and P. Turner (2003). Controlling for Currency Mismatches in Emerging Economies. Mimeo, Institute for International Economics.

Herrera, L. O. and R. Valdez (2003). Dedollarization, Indexation and Nominalization: The Chilean Experience. Mimeo, Central Bank of Chile.

Ize, A. and E. Levy-Yeyati (2003). Financial Dollarization. Journal of International Economics, 59.

Jeanne, O. and J. Zettelmeyer (2001) "International Bailouts, Moral Hazard, and Conditionality," Economic Policy 16, issue No 33, October.

Levy-Yeyati, E. (2004). Financial Dollarization: Evaluating the Consequences. Mimeo, http://www.utdt.edu/ ely.

Levy-Yeyati, E., M. S. Martínez Pería, and S. Schmukler (2004). Market Discipline under Systemic Risk:Evidence from Bank Runs in Emerging Economies. Mimeo. The World Bank.

Martínez, L. and A. Werner (2002). Capital Markets in Mexico: Recent Developments and Future Challenges. Mimeo, Central Bank of Mexico.

Rajan, R. (2004). How Useful Are Clever Solutions? Finance \& Development, March 2004.

Thomas, L.R. (1985). Portfolio Theory and Currency Substitution. Journal of Money, Credit, and Banking, Vol. 17. 
Table 1. Sources of Financial Dollarization

(non-industrial economies excluding offshore centers; as percent of GDP)

\begin{tabular}{|c|c|c|c|c|c|c|c|c|}
\hline & & $\begin{array}{c}\text { Onshore dollar } \\
\text { Deposits } \\
\text { (a) } \\
\end{array}$ & $\begin{array}{c}\text { External loans } \\
\text { (b) } \\
\end{array}$ & $\begin{array}{c}\text { Dollar bonded } \\
\text { external debt } \\
\text { (c) } \\
\end{array}$ & $\begin{array}{c}\text { IFI lending } \\
\text { (d) } \\
\end{array}$ & $\begin{array}{c}\text { IMF lending } \\
\text { (e) } \\
\end{array}$ & $\begin{array}{l}\text { Total external } \\
(\mathbf{b})+(c)+(d)+(e) \\
\end{array}$ & Total \\
\hline \multirow{5}{*}{1996} & Mean & 0.0825 & 0.1427 & 0.0406 & 0.2238 & 0.0130 & 0.4201 & 0.5027 \\
\hline & Median & 0.0625 & 0.1297 & 0.0272 & 0.0872 & 0.0055 & 0.3323 & 0.4326 \\
\hline & Min & 0 & 0.0271 & 0.0014 & 0 & 0 & 0.09118 & 0.1185 \\
\hline & Max & 0.3390 & 0.5295 & 0.2937 & 2.4379 & 0.0591 & 2.6977 & 2.9492 \\
\hline & Obs. & 30 & 30 & 30 & 30 & 30 & 30 & 30 \\
\hline \multirow{5}{*}{2001} & Mean & 0.1197 & 0.1286 & 0.0908 & 0.1838 & 0.0183 & 0.4214 & 0.5411 \\
\hline & Median & 0.0823 & 0.1207 & 0.0583 & 0.0964 & 0.0028 & 0.3479 & 0.4422 \\
\hline & Min & 0.0003 & 0.0359 & 0.0019 & 0.0011 & 0 & 0.1783 & 0.1814 \\
\hline & Max & 0.5101 & 0.2484 & 0.3251 & 1.973382 & 0.0987 & 2.2831 & 2.7932 \\
\hline & Obs. & 30 & 30 & 30 & 30 & 30 & 30 & 30 \\
\hline
\end{tabular}

Countries in the sample: Argentina, Bulgaria, Chile, Costa Rica, Czech Republic, Dominican Republic, Egypt, Estonia, Guatemala, Croatia, Hungary, Indonesia, Jamaica, Kazakhstan, Lithuania, Latvia, Moldova, Mexico, Malaysia, Nicaragua, Peru, Philippines, Poland, Romania, Slovak Republic, Thailand, Turkey, Uruguay, Venezuela and South Africa. 
Table 2

Measures of Financial Dollarization - Correlation Matrix

(non-industrial economies excluding offshore centers; period averages)

\begin{tabular}{|c|c|c|c|c|c|c|c|}
\hline & $\begin{array}{l}\text { Onshore } \\
\text { deposits }\end{array}$ & $\begin{array}{c}\text { Deposit } \\
\text { Offshoriz. }\end{array}$ & $\begin{array}{l}\text { Deposit } \\
\text { dollariz. }\end{array}$ & $\begin{array}{c}\text { Dollar external } \\
\text { liabilities (exc. IFIs) }\end{array}$ & $\begin{array}{l}\text { IFI lending } \\
\text { (exc. IMF) }\end{array}$ & IMF lending & $\begin{array}{c}\text { IFI lending / } \\
\text { Total ext. liabilities }\end{array}$ \\
\hline Deposit offshorization & $\begin{array}{c}-0.5754 \\
(0.0011) \\
29\end{array}$ & & & & & & \\
\hline Deposit dollarization & $\begin{array}{c}-0.4163 \\
(0.0540) \\
22\end{array}$ & $\begin{array}{c}0.6157 \\
(0.0023) \\
22\end{array}$ & & & & & \\
\hline Dollar external liabilities (exc. IFIs) & $\begin{array}{c}0.4209 \\
(0.0455) \\
23\end{array}$ & $\begin{array}{c}-0.1966 \\
(0.3687) \\
23\end{array}$ & $\begin{array}{c}-0.1390 \\
(0.5588) \\
20\end{array}$ & & & & \\
\hline IFI lending (exc. IMF) & $\begin{array}{c}-0.2383 \\
(0.2313) \\
27\end{array}$ & $\begin{array}{c}0.3060 \\
(0.1284) \\
26\end{array}$ & $\begin{array}{c}0.2052 \\
(0.3722) \\
21\end{array}$ & $\begin{array}{c}-0.4280 \\
(0.0469) \\
22\end{array}$ & & & \\
\hline IMF lending & $\begin{array}{c}-0.2714 \\
(0.1709) \\
27\end{array}$ & $\begin{array}{c}0.1701 \\
(0.4062) \\
26\end{array}$ & $\begin{array}{c}0.2676 \\
(0.2408) \\
21\end{array}$ & $\begin{array}{c}-0.1778 \\
(0.4285) \\
22\end{array}$ & $\begin{array}{c}0.2520 \\
(0.2048) \\
27\end{array}$ & & \\
\hline IFI lending / Total ext. liabilities & $\begin{array}{c}-0.1388 \\
0.4900 \\
27\end{array}$ & $\begin{array}{c}0.0674 \\
0.7437 \\
26\end{array}$ & $\begin{array}{c}0.2008 \\
0.3828 \\
21\end{array}$ & $\begin{array}{c}-0.5304 \\
0.0111 \\
22\end{array}$ & $\begin{array}{c}0.7951 \\
0.0000 \\
27\end{array}$ & $\begin{array}{c}0.1568 \\
0.4347 \\
27\end{array}$ & \\
\hline Country risk & $\begin{array}{c}-0.5646 \\
(0.0012) \\
30\end{array}$ & $\begin{array}{c}0.3678 \\
(0.0496) \\
29\end{array}$ & $\begin{array}{c}0.5047 \\
(0.0166) \\
22\end{array}$ & $\begin{array}{c}-0.1886 \\
(0.3774) \\
24\end{array}$ & $\begin{array}{c}0.5633 \\
(0.0022) \\
27\end{array}$ & $\begin{array}{c}0.5073 \\
(0.0069) \\
27\end{array}$ & $\begin{array}{c}0.3896 \\
(0.0445) \\
27\end{array}$ \\
\hline
\end{tabular}

Note: Significance levels in parentheses. Number of observations in italics.

Averages computed based on observations for which the country risk index is available. All variables computed over GDP (with the exception of the ratio of IFI lending to total external liabilities and the country risk index). 
Table 3

Country Risk, Offshorization and Deposit Dollarization (non-industrial economies excluding offshore centers)

\begin{tabular}{|c|c|c|c|c|c|c|c|c|c|c|c|}
\hline & \multirow{2}{*}{\multicolumn{3}{|c|}{$\begin{array}{c}\text { Onshore deposits over GDP } \\
\text { OLS (period averages) }\end{array}$}} & \multirow{2}{*}{\multicolumn{3}{|c|}{$\begin{array}{c}\text { Deposit offshorization ratio } \\
\text { OLS (period averages) }\end{array}$}} & \multicolumn{5}{|c|}{ Deposit dollarization ratio } \\
\hline & & & & & & & \multicolumn{3}{|c|}{ OLS (period averages) } & \multicolumn{2}{|c|}{ FE (annual data) } \\
\hline & (1) & $(2)$ & (3) & (4) & (5) & (6) & (7) & (8) & (9) & (10) & (11) \\
\hline Country risk & $\begin{array}{c}-0.030 * * * \\
(0.007)\end{array}$ & $\begin{array}{c}-0.039 * * * \\
(0.008)\end{array}$ & $\begin{array}{c}-0.031 * * * \\
(0.008)\end{array}$ & $\begin{array}{c}0.021 * * * \\
(0.008)\end{array}$ & $\begin{array}{l}0.026^{*} \\
(0.013)\end{array}$ & $\begin{array}{l}0.020^{*} \\
(0.010)\end{array}$ & $\begin{array}{l}0.018 * \\
(0.009)\end{array}$ & $\begin{array}{c}0.006 \\
(0.005)\end{array}$ & & $\begin{array}{c}0.004 * * \\
(0.002)\end{array}$ & \\
\hline Onshore dep. doll. ratio & & $\begin{array}{c}0.089 \\
(0.164)\end{array}$ & & & $\begin{array}{l}-0.020 \\
(0.221)\end{array}$ & & & & & & \\
\hline Restrictions & & & $\begin{array}{c}0.045 \\
(0.047)\end{array}$ & & & $\begin{array}{l}-0.045^{*} \\
(0.023)\end{array}$ & & & & & \\
\hline Underlying doll. ratio & & & & & & & $\begin{array}{c}0.426^{* * * *} \\
(0.089)\end{array}$ & $\begin{array}{c}0.413 * * * \\
(0.066)\end{array}$ & $\begin{array}{l}0.274 * * * \\
(0.054)\end{array}$ & & \\
\hline Dep. offshorization ratio & & & & & & & & $\begin{array}{c}0.455 * * * \\
(0.116)\end{array}$ & $\begin{array}{c}0.334 * * * \\
(0.072)\end{array}$ & $\begin{array}{c}0.514 * * * \\
(0.069)\end{array}$ & $\begin{array}{c}0.116^{* * *} \\
(0.029)\end{array}$ \\
\hline Constant & $\begin{array}{c}0.560^{* * *} \\
(0.069)\end{array}$ & $\begin{array}{c}0.588^{* * * *} \\
(0.092)\end{array}$ & $\begin{array}{c}0.521 * * * \\
(0.072)\end{array}$ & $\begin{array}{c}0.272 * * * \\
(0.064)\end{array}$ & $\begin{array}{l}0.240 * * * \\
(0.069)\end{array}$ & $\begin{array}{l}0.298 * * * \\
(0.069)\end{array}$ & $\begin{array}{c}0.261 * * * \\
(0.054)\end{array}$ & $\begin{array}{c}0.154 * * \\
(0.054)\end{array}$ & $\begin{array}{c}0.303 * * * \\
(0.044)\end{array}$ & $\begin{array}{c}0.282^{* * *} * \\
(0.027)\end{array}$ & $\begin{array}{c}0.423 * * * \\
(0.078)\end{array}$ \\
\hline Observations & 30 & 23 & 24 & 29 & 22 & 26 & 21 & 21 & 78 & 107 & 584 \\
\hline R-squared & 0.32 & 0.39 & 0.35 & 0.14 & 0.20 & 0.19 & 0.68 & 0.83 & 0.52 & 0.98 & 0.96 \\
\hline
\end{tabular}

Robust standard errors in parentheses

* significant at $10 \% ; * *$ significant at $5 \% ; * * *$ significant at $1 \%$

FE regressions include year dummies. 
Table 4

Offshorization, IFI lending and IMF lending

(non-industrial economies excluding offshore centers)

\begin{tabular}{|c|c|c|c|c|c|c|c|c|}
\hline & \multicolumn{4}{|c|}{ IFI lending over GDP (exc. IMF) } & \multicolumn{4}{|c|}{ IMF lending over GDP } \\
\hline & \multicolumn{2}{|c|}{ OLS (averages) } & \multicolumn{2}{|c|}{ FE (annual data) } & \multicolumn{2}{|c|}{ OLS (averages) } & \multicolumn{2}{|c|}{ FE (annual data) } \\
\hline & $(1)^{1}$ & (2) & (3) & (4) & $(5)^{1}$ & (6) & (7) & (8) \\
\hline Deposit offshorization & $\begin{array}{c}0.253 \\
(0.161)\end{array}$ & $\begin{array}{c}0.560 * * * \\
(0.141)\end{array}$ & $\begin{array}{c}0.050 * * \\
(0.025)\end{array}$ & $\begin{array}{c}0.147 * * \\
(0.060)\end{array}$ & $\begin{array}{c}0.017 \\
(0.020)\end{array}$ & $\begin{array}{c}0.036 * * * \\
(0.012)\end{array}$ & $\begin{array}{c}0.005 * * \\
(0.002)\end{array}$ & $\begin{array}{c}0.047 * * \\
(0.024)\end{array}$ \\
\hline Country risk & & & & $\begin{array}{c}0.008 * * * \\
(0.002)\end{array}$ & & & & $\begin{array}{c}0.001 \\
(0.001)\end{array}$ \\
\hline Constant & $\begin{array}{c}0.094 \\
(0.069)\end{array}$ & $\begin{array}{c}0.240 * * * \\
(0.069)\end{array}$ & $\begin{array}{c}0.504 * * * \\
(0.019)\end{array}$ & $\begin{array}{c}0.099 * * * \\
(0.024)\end{array}$ & $\begin{array}{c}0.010 \\
(0.009)\end{array}$ & $\begin{array}{c}0.011 * * \\
(0.006)\end{array}$ & $\begin{array}{c}0.027 * * * \\
(0.002)\end{array}$ & $\begin{array}{c}-0.004 \\
(0.013)\end{array}$ \\
\hline Observations & 26 & 120 & 815 & 125 & 26 & 120 & 816 & 125 \\
\hline R-squared & 0.09 & 0.08 & 0.96 & 0.98 & 0.03 & 0.07 & 0.92 & 0.82 \\
\hline
\end{tabular}

Robust standard errors in parentheses.

* significant at $10 \%$; * significant at 5\%; *** significant at $1 \%$

${ }^{1}$ Includes observations for which the country risk index is available. 
Table 5

Offshorization and liability dollarization

(non-industrial economies excluding offshore centers)

\begin{tabular}{|c|c|c|c|c|c|c|c|c|}
\hline & \multicolumn{2}{|c|}{$\begin{array}{c}\text { Dollar external liabilities } \\
\text { over GDP (exc. IFIs) }\end{array}$} & \multicolumn{2}{|c|}{$\begin{array}{c}\text { Total external liabilities } \\
\text { over GDP (exc. IFIs) }\end{array}$} & \multirow{2}{*}{\multicolumn{2}{|c|}{$\begin{array}{c}\text { Liability dollarization ratio } \\
\text { (exc. IMF) } \\
\text { OLS (averages) } \\
\end{array}$}} & \multirow{2}{*}{\multicolumn{2}{|c|}{$\begin{array}{c}\text { Liability dollarization ratio } \\
\text { OLS (averages) }\end{array}$}} \\
\hline & OLS (avgs.) & FE (annual) & OLS (avgs.) & FE (annual) & & & & \\
\hline & (1) & (2) & (3) & (4) & (5) & $(6)^{1}$ & (7) & $(8)^{2}$ \\
\hline Deposit offshorization & $\begin{array}{l}-0.108 \\
(0.099)\end{array}$ & $\begin{array}{c}0.015 \\
(0.013)\end{array}$ & $\begin{array}{l}-0.021 \\
(0.030)\end{array}$ & $\begin{array}{c}0.022 \\
(0.014)\end{array}$ & $\begin{array}{c}0.154 * * \\
(0.063)\end{array}$ & $\begin{array}{l}0.132 * * * \\
(0.042)\end{array}$ & $\begin{array}{c}0.156 * * \\
(0.063)\end{array}$ & $\begin{array}{l}0.131 * * * \\
(0.034)\end{array}$ \\
\hline Constant & $\begin{array}{l}0.260 * * * \\
(0.048)\end{array}$ & $\begin{array}{l}0.165 * * * \\
(0.027)\end{array}$ & $\begin{array}{l}0.139 * * * \\
(0.019)\end{array}$ & $\begin{array}{l}0.101 * * * \\
(0.009)\end{array}$ & $\begin{array}{c}0.422 * * * \\
(0.034)\end{array}$ & $\begin{array}{c}0.467 * * * \\
(0.026)\end{array}$ & $\begin{array}{c}0.425^{* * *} \\
(0.034)\end{array}$ & $\begin{array}{c}0.472 * * * \\
(0.022)\end{array}$ \\
\hline Observations & 23 & 301 & 120 & 815 & 38 & 88 & 38 & 88 \\
\hline R-squared & 0.04 & 0.75 & 0.00 & 0.84 & 0.14 & 0.15 & 0.14 & 0.15 \\
\hline
\end{tabular}

Robust standard errors in parentheses.

* significant at $10 \%$; * significant at $5 \%$; *** significant at $1 \%$

${ }^{1}$ Uses total long-term external debt as a proxy for dollar lon-term external debt. 
Table 6.

Pension fund invesments in foreign assets

(emerging economies with private social security systems)

\begin{tabular}{|c|c|c|}
\hline & Legal framework ${ }^{(*)}$ & $\begin{array}{l}\text { Foreign assets } \\
\text { share }^{(* *)}\end{array}$ \\
\hline Argentina & Up to $10 \%$ of the Fund's total asset value. & 9.04 \\
\hline Chile & Up to $20 \%$ of the Fund's asset value. & 23.89 \\
\hline Mexico & $\begin{array}{l}\text { Although the SIEFORES Law determines that total investment in } \\
\text { instruments denominated in foreign currencies (U.S. Dollars, Euros, } \\
\text { Yens) must not exceed the } 10 \% \text { of the Fund's total asset value, no } \\
\text { restrictions have been placed on the issuer's origin. }\end{array}$ & 8.77 \\
\hline Colombia & $\begin{array}{l}\text { As regards compulsory pensions, up to } 10 \% \text { of the Fund's total value } \\
\text { can be invested in foreign assets (rule effective since September } 1 \text { st } \\
\text { 2001). On the other hand, no quantitative limits have been set for } \\
\text { voluntary pensions, although the law requires that the issuer be } \\
\text { awarded the "investment grade" status by credit rating agencies. }\end{array}$ & 7.36 \\
\hline Peru & Up to $10 \%$ of the Fund's asset value. & 8.77 \\
\hline Bolivia & No less than $10 \%$ or greater than $50 \%$ of the Fund's asset value. & n.a. \\
\hline
\end{tabular}

(*) Amongst others, it includes assets issued or backed by foreign governments and central banks or commercial banks (both foreign and international), stocks and corporate bonds, mutual funds and foreign stock indices.

$\left({ }^{* *}\right)$ Obtained as the ratio of funds invested in foreign assets to total fund's portfolio value at December 2003. For Peru, the last available data belongs to August 2003.

Source: FIAP, national pensions regulators and supervisors and national pension funds unions. 
Table 7

Pension fund stocks and flows, offshore deposits and IFI lending (emerging economies with private social security systems)

\begin{tabular}{|c|c|c|c|c|c|c|}
\hline & \multicolumn{3}{|c|}{$\begin{array}{c}\text { Pension fund } \\
\text { (2003) }\end{array}$} & \multirow{2}{*}{$\begin{array}{c}\text { Offshore Deposits } \\
\text { (2002) }\end{array}$} & \multirow{2}{*}{$\begin{array}{c}\text { IFI lending } \\
\text { (exc. IMF) } \\
\text { (Dec. 2001) }\end{array}$} & \multirow{2}{*}{$\begin{array}{l}\text { IMF lending } \\
\text { (2003) }\end{array}$} \\
\hline & Initial Year & Gross Inflows & Stocks & & & \\
\hline \multicolumn{7}{|l|}{ LATAM } \\
\hline ARGENTINA & 1994 & 956 & 15,947 & 23,413 & 21,211 & 15,466 \\
\hline BOLIVIA & 1997 & 192 & 1,485 & 1,176 & 3,103 & 278 \\
\hline COLOMBIA & 1994 & 775 & 7,326 & 7,252 & 8,591 & - \\
\hline COSTA RICA & 2001 & 167 & 304 & 3,234 & 1,654 & - \\
\hline CHILE & 1981 & 6,206 & 49,691 & 13,242 & 1,751 & - \\
\hline EL SALVADOR & 1998 & 476 & 1,572 & 1,006 & 2,563 & - \\
\hline MÉXICO & 1997 & 6,765 & 35,844 & 48,616 & 19,852 & - \\
\hline PERU & 1993 & 754 & 6,341 & 5,894 & 14,688 & 139 \\
\hline DOMINICAN REP. & 2003 & 34 & 34 & 2,391 & 2,447 & 130 \\
\hline URUGUAY & 1996 & 112 & 1,232 & 7,500 & 2,302 & 2,407 \\
\hline \multicolumn{7}{|l|}{ EUROPE / ASIA } \\
\hline BULGARIA & 2000 & 13 & 134 & 2,965 & N.A. & 1,183 \\
\hline KAZAJSTAN & 1998 & N.A. & 2,631 & 1,383 & 2,148 & - \\
\hline POLONIA & 2000 & 2,822 & 11,058 & 19,378 & 17,810 & - \\
\hline TOTAL & & 19,272 & 133,602 & 137,450 & 98,120 & 19,602 \\
\hline
\end{tabular}

Source: FIAP, national pensions supervisory agencies, national pension funds unions, BIS, IMF and GDF (World Bank). Gross inflows for Costa Rica, El Salvador, Dominican Republic and Bulgaria obtained as the difference between the stock of assets for 2003 and 2002 (both informed by FIAP). 


\section{Appendix I}

\section{Variable sources and definitions}

- Onshore dollar (peso) deposits: Foreign (local) currency deposits with domestic banks. Source: Levy Yeyati (2004).

- Onshore deposits: Onshore dollar deposits + Onshore peso deposits.

- Offshore deposits: Cross-border deposits by residents with banks domiciled in BIS reporting countries. Source: Bank of International Settlements (BIS).

- Total deposits: Offshore deposits + Onshore deposits.

- Deposit offshorization ratio: Offshore deposits / Total deposits.

- Deposit dollarization ratio: (Onshore dollar deposits + offshore deposits) / Total deposits.

- Onshore deposit dollarization ratio: Onshore dollar deposits / Onshore deposits.

- External loans: Cross-border loans to residents from banks domiciled in BIS reporting countries. Source: BIS.

- Dollar (peso) bonded external debt: Private and public external bonds denominated in foreign (local) currency; stocks outstanding. Source: BIS.

- IFI lending: Long-term debt with official creditors. Public and publicly guaranteed debt from official creditors includes loans from international organizations (multilateral loans) and loans from governments (bilateral loans). Source: Global Development Finance 2003 (GDF 2003). Units: US dollars. Scale: millions.

- IMF lending: Use of IMF credit. Denotes repurchase obligations to the IMF with respect to all uses of IMF resources, excluding those resulting from drawings in the reserve tranche. Source: GDF.

- Dollar external liabilities: External loans + Dollar bonded external debt + IFI lending.

- Total external debt: Includes public and publicly guaranteed long-term debt, private nonguaranteed long-term debt, use of IMF credit, and estimated short-term debt outstanding. Source: GDF.

- Short-term external debt: Defined as debt that has an original maturity of one year or less. Source: GDF.

- Total long-term external debt: Total external debt minus short-term external debt. Used in some tests as an alternative measure of dollar external liabilities. Source: GDF. 
- Liability dollarization ratio: (Dollar external liabilities + Dollar onshore deposits)/(Dollar external liabilities + Peso bonded debt + onshore deposits). The currency composition of deposits is used to proxy the currency composition of domestic loans.

- Country risk: J.P. Morgan Bond EMBI Global index. Included in the EMBI Global are US dollar denominated Brady bonds, Eurobonds, traded loans and local market debt instruments issued by sovereign and quasi-sovereign entities. Source: J.P. Morgan.

- Restrictions: Index of restrictiveness of rules on resident holdings of foreign currency deposits onshore as of beginning of 2001. Source: Levy Yeyati (2004) based on IMF, 2001 Annual Report on Exchange Arrangements and Exchange Restrictions, following the methodology proposed by De Nicoló et al. (2003).

- Underlying Dollarization Ratio: $(\operatorname{Var}(\pi)-\operatorname{Cov}(\pi, s)) /(\operatorname{Var}(\pi)+\operatorname{Var}(\mathrm{s})-2 \operatorname{Cov}(\pi, \mathrm{s}))$, where $\pi$ and $\mathrm{s}$ are the monthly inflation and real devaluation rates. Source: IMF, International Financial Statistics (IFS). 
Deposit dollarization data: Countries and periods covered

\begin{tabular}{|c|c|c|c|c|c|c|c|}
\hline Country & Dollariz. & Country & Dollariz. & Country & Dollariz. & Country & Dollariz. \\
\hline Albania & $1992-2001$ & Ecuador* & 1990-1999 & Lebanon & $1993-2001$ & Sierra Leone & 1993-1999 \\
\hline Angola & $1995-2001$ & Egypt & $1980-2001$ & Lithuania** & $1993-2001$ & Slovak Republic** & $1993-2001$ \\
\hline Antigua and Barbuda* & 1979-2001 & El Salvador* & $1982-2001$ & Macedonia, FYR** & $1997-2001$ & Slovenia** & 1991-2001 \\
\hline Argentina* & $1981-2001$ & Estonia** & $1991-2001$ & Malawi & 1994-2001 & South Africa & 1991-2001 \\
\hline Armenia** & $1992-2001$ & Ethiopia & 1998-1999 & Malaysia & $1996-2001$ & Spain & 1996-2001 \\
\hline Austria & $1997-2001$ & Finland & 1996-2001 & Maldives & 1981-1999 & St. Kitts and Nevis* & $1979-2001$ \\
\hline Azerbaijan** & $1992-2001$ & Georgia** & $1992-2001$ & Malta & $1975-1984$ & St. Lucia* & 1979-1999 \\
\hline Bahamas, The & $1975-2001$ & Ghana & $1995-2000$ & Mauritius & 1992-1999 & St. Vincent \& Grens.* & ' $1979-2001$ \\
\hline Bangladesh & $1987-2001$ & Greece & $1990-2001$ & Mexico* & $1991-2002$ & Sudan & 1992-1998 \\
\hline Bahrain & 1984-1997 & Grenada* & 1979-1999 & Moldova** & 1994-2001 & Suriname* & 1975 \\
\hline Barbados* & $1975-2001$ & Guatemala* & $1995-2002$ & Mongolia** & $1992-2001$ & Sweden & 1994-2001 \\
\hline Belarus** & $1992-2001$ & Guinea & 1989-2001 & Mozambique & $1991-2001$ & Switzerland & $1998-2001$ \\
\hline Belize & $1976-2001$ & Guinea-Bissau & 1990-1996 & Myanmar & 1991-1999 & Syrian Arab Republic & $1975-1998$ \\
\hline Bhutan & $1993-2001$ & Haiti* & 1994-2001 & Netherlands & $1990-2001$ & Tajikistan* & $1996-2000$ \\
\hline Bolivia* & $1975-2001$ & Honduras* & $1990-2001$ & Netherlands Antilles* & $1975-2001$ & Tanzania & 1993-2001 \\
\hline Bosnia and Herzeg.** & $1996-2001$ & Hong Kong & $1991-2001$ & New Zealand & $1990-2001$ & Thailand & $1982-2001$ \\
\hline Bulgaria** & $1991-2001$ & Hungary** & $1989-2001$ & Nicaragua* & $1990-2001$ & Trinidad and Tobago & 1993-2001 \\
\hline Cape Verde & 1995-1999 & Iceland & 1978-1999 & Nigeria & 1994-2001 & Turkey & $1986-2001$ \\
\hline Cambodia & $1993-2001$ & Indonesia & $1992-2001$ & Norway & $1996-2000$ & Turkmenistan** & $1993-2000$ \\
\hline Chile* & $1976-2001$ & Israel & $1981-2001$ & Oman & 1975-1999 & Tonga & 1994-1999 \\
\hline China,P.R.: Mainland & $1998-2001$ & Italy & $1996-2000$ & Pakistan & 1990-1998 & Uzbekistan & 1997-1999 \\
\hline Colombia* & 1990-1999 & Jamaica* & $1992-2001$ & Papua New Guinea & 1976-1999 & Uganda & $1992-2000$ \\
\hline Comoros & $1998-2001$ & Japan & $1996-2001$ & Paraguay* & $1988-2001$ & Ukraine** & 1992-2001 \\
\hline Congo, Dem. Rep. & $1975-2001$ & Jordan & 1990-1999 & Peru* & $1975-2001$ & United Arab Emirates & $1981-2001$ \\
\hline Costa Rica* & $1990-2002$ & Kazakhstan** & $1998-2001$ & Philippines & $1982-2001$ & United Kingdom & 1990-2001 \\
\hline Croatia** & $1993-2001$ & Kenya & $1995-2001$ & Poland** & $1985-2001$ & Uruguay* & $1981-2001$ \\
\hline Czech Republic** & $1993-2001$ & Korea & $1990-2001$ & Qatar & 1993-1999 & Vanuatu & 1981-1999 \\
\hline Cyprus & 1991-1999 & Kuwait & 1981-1999 & Romania** & $1990-2001$ & Venezuela* & 1994-2001 \\
\hline Denmark & $1991-2001$ & Kyrgyz Republic** & $1995-2001$ & Russia** & $1993-2001$ & Vietnam & 1992-2001 \\
\hline Dominica* & $1988-2001$ & Lao People's Dem. Rep. & $1989-2001$ & Rwanda & 1994-1999 & Yemen & $1990-2001$ \\
\hline \multirow[t]{2}{*}{ Dominican Republic } & $1996-2001$ & Latvia** & $1992-2001$ & Sao Tome \& Principe & $1995-2001$ & Zambia & 1994-2001 \\
\hline & & & & Saudi Arabia & $1975-2001$ & Zimbabwe & 1993-1999 \\
\hline
\end{tabular}

Note: $(*)$ denotes Latin American countries and $(* *)$ denotes Transition countries. 
Emerging Market Bond Index Global: Countries and periods covered

\begin{tabular}{lclc}
\hline Country & Period covered & Country & Period covered \\
\hline Algeria & $1999-2003$ & Malaysia & $1996-2003$ \\
Argentina* & $1993-2003$ & Nigeria & $1993-2003$ \\
Bulgaria** & $1994-2003$ & Pakistan & $2001-2003$ \\
Brazil* & $1994-2003$ & Panama* & $1996-2003$ \\
Chile* & $1999-2003$ & Peru* & $1997-2003$ \\
China: Mainland & $1994-2003$ & Philippines & $1997-2003$ \\
Cote D'Ivoire & $1998-2003$ & Poland & $1994-2003$ \\
Colombia* & $1997-2003$ & Russia** & $1997-2003$ \\
Croatia** & $1996-2003$ & El Salvador* & $2002-2003$ \\
Dominican Republic* & $2001-2003$ & Thailand & $1997-2003$ \\
Ecuador* & $1995-2003$ & Tunisia & $2002-2003$ \\
Egypt & $2001-2003$ & Ukraine & $2000-2003$ \\
Hungary & $1999-2003$ & Turkey & $1996-2003$ \\
Korea & $1993-2003$ & Uruguay* & $2001-2003$ \\
Lebanon & $1995-2003$ & Venezuela* & $1993-2003$ \\
Morocco & $1997-2003$ & South Africa & $1994-2003$ \\
México* & $1993-2003$ & & \\
\hline
\end{tabular}

Notes: $(*)$ denotes Latin American countries and $\left({ }^{* *}\right)$ denotes Transition countries.

Source: JP-Morgan. 


\section{Appendix II}

\section{Non-binding offshorization}

First note that, from (1),

$$
r^{C H}=r^{H}-r^{F}+r^{C F}+\theta
$$

which implies that

$$
\theta=E\left(r^{C H}\right)-\left[E\left(r^{H}\right)-E\left(r^{F}\right)+E\left(r^{C F}\right)\right]=0
$$

to rule out arbitrage between a portfolio $x_{H}-x^{F}+x_{C F}$ and $x_{C H}$.

Then, using $x^{H}+x^{F}+x^{C F}+x^{C H}=1$ and $r^{C H}=r^{H}-r^{F}+r^{C F}$, we obtain $r=\left(x^{F}-x^{C H}\right)\left(r^{F}-r^{H}\right)+\left(x^{C F}+x^{C H}\right)\left(r^{C F}-r^{H}\right)+r^{H}$, so that the investor's problem can now be written as:

$$
\begin{gathered}
\max _{\left\{x_{F}-x_{C H}, x_{C F}+x_{C H}\right\}} U=E(r)-\frac{c}{2} \operatorname{Var}(r) \\
\text { s.t. } x_{F}, x_{H}, x_{C F}, x_{C H} \geq 0
\end{gathered}
$$

where

$$
E(r)=\mathbf{x}^{\prime} \mathbf{w}+E\left(r^{H}\right)
$$

and

$$
\operatorname{Var}(r)=\mathbf{x}^{\prime} \mathbf{B} \mathbf{x}+2 \mathbf{C x}+\operatorname{Var}\left(r_{H}\right)
$$

with

$$
\begin{gathered}
\mathbf{x}=\left(\begin{array}{c}
\lambda-\gamma \\
\gamma
\end{array}\right), \\
\mathbf{w}=E\left(\begin{array}{c}
r^{F}-r^{H} \\
r^{C F}-r^{H}
\end{array}\right), \\
\mathbf{B}=\left(\begin{array}{cc}
V & V \\
V & V+S_{c c}
\end{array}\right),
\end{gathered}
$$


and

$$
\mathbf{C}=-\left(\begin{array}{c}
S_{\pi \pi}+S_{\pi s} \\
S_{\pi \pi}+S_{\pi s}+S_{c c}
\end{array}\right) .
$$

The first order conditions with respect to $\mathbf{x}$ can be expressed as:

$$
-\frac{\mathbf{w}}{c}+\mathbf{B} \mathbf{x}+\mathbf{C}=0
$$

from which we obtain:

$$
\mathbf{x}=\mathbf{B}^{-1}\left[-\mathbf{C}+\frac{\mathbf{w}}{c}\right]=\boldsymbol{\lambda}_{\mathbf{u}}+\frac{\mathbf{B}^{-1}}{c} \mathbf{w}
$$

or

$$
\begin{aligned}
\left(\begin{array}{c}
\lambda-\gamma \\
\gamma
\end{array}\right)= & \frac{1}{V S_{c c}}\left(\begin{array}{cc}
V+S_{c c} & -V \\
-V & V
\end{array}\right)\left(\begin{array}{c}
S_{\pi \pi}+S_{\pi s} \\
S_{\pi \pi}+S_{\pi s}+S_{c c}
\end{array}\right) \\
& +\frac{1}{c V S_{c c}}\left(\begin{array}{cc}
V+S_{c c} & -V \\
-V & V
\end{array}\right) E\left(\begin{array}{c}
r^{F}-r^{H} \\
r^{C F}-r^{H}
\end{array}\right) .
\end{aligned}
$$

Interest rate arbitrage by risk-neutral borrowers implies that

$$
r=E\left(r^{H}\right)=E\left(r^{F}\right)=r^{C}=E\left(r^{C F}\right)+\phi .
$$

from which the dollarization and offshorization ratios are given by:

$$
\left(\begin{array}{l}
\lambda \\
\gamma
\end{array}\right)=\left(\begin{array}{c}
\lambda_{u} \\
1-\frac{1}{c} \times \frac{E\left(r^{F}-r^{C F}\right)}{S_{c c}}
\end{array}\right),
$$

where

$$
\lambda_{u} \equiv \frac{S_{\pi \pi}+S_{\pi s}}{V}
$$

denotes the underlying dollarization ratio. 


\section{Binding offshorization and liability dollarization}

Offshorization is binding iff $\lambda_{u}<\gamma$, or

$$
\frac{1}{c} \times \frac{E\left(r^{F}-r^{C F}\right)}{S_{c c}}<1-\lambda_{u} .
$$

In turn, noting that, combining (9) and (A.8),

$$
\lambda^{B} L=L-\left(1-\lambda_{u}\right) S
$$

and

$$
E\left(r^{F}-r^{C F}\right)=\phi\left[L-\left(1-\lambda_{u}\right) S\right]
$$

we can rewrite condition (A.9) as

$$
S_{c c}>\frac{\phi\left[L-\left(1-\lambda_{u}\right) S\right]}{c\left(1-\lambda_{u}\right)}
$$

If the previous condition is satisfied, $x^{F}=0$ in equilibrium. Thus, in the absence of foreign peso assets, the investor's problem can now be written as:

$$
\max _{\left\{x_{H}+x_{F}\right\}} U=E(r)-\frac{c}{2} \operatorname{Var}(r)
$$

where, using $x_{H}+x_{C F}=1$,

$$
r=x_{C F}\left(r^{C F}-r^{H}\right)+r^{H}
$$

from which the first and second moments of the probability distribution of portfolio real returns can be expressed as

$$
E(r)=x_{C F} E\left(r^{C F}-r^{H}\right)+E\left(r^{H}\right)
$$

and

$$
\operatorname{Var}(r)=x_{C F}^{2}\left(V+S_{c c}+2 S_{c s}+2 S_{c \pi}\right)-2 x_{C F}\left(S_{\pi \pi}+S_{\pi s}+S_{c s}+2 S_{c \pi}+S_{c c}\right)+\operatorname{Var}\left(r^{H}\right)
$$

In turn, from the first order condition with respect to $x_{C F}$, 


$$
\gamma>\underline{\gamma}=\underline{\lambda}=x_{C F}=\frac{\left(S_{\pi \pi}+S_{\pi s}+S_{c c}\right)}{\left(V+S_{c c}\right)}-\frac{1}{c} \times \frac{E\left(r^{H}-r^{C F}\right)}{\left(V+S_{c c}\right)}>\lambda,
$$

where

$$
\Delta \equiv \underline{\lambda}-\lambda_{u}=\left(1-\lambda_{u}\right) \times\left(\frac{S_{c c}}{V+S_{c c}}\right)-\frac{1}{c} \times \frac{E\left(r^{H}-r^{C F}\right)}{V+S_{c c}}
$$

and

$$
\frac{\partial \Delta}{\partial S_{c c}}=\left(1-\lambda_{u}\right) \times\left(\frac{V}{V+S_{c c}}\right)+\frac{1}{c} \times \frac{E\left(r^{H}-r^{C F}\right)}{\left(V+S_{c c}\right)^{2}}>0,
$$

so that the additional dollarization induced by offshorization in the absence of a country risk-free peso assets is increasing in country risk

Finally, substituting $\lambda=\underline{\lambda}$ into the balance of funds equation (9) and rearranging, we obtain

$$
\lambda^{B}=1-\left(1-\frac{S_{\pi \pi}+S_{\pi s}+S_{c c}}{V+S_{c c}}+\frac{1}{c} \times \frac{\phi\left(\lambda^{B} L\right)}{V+S_{c c}}\right) \frac{S}{L},
$$

from which it is immediate to see that liability dollarization increases with country risk, since

$$
\frac{\partial \lambda^{B}}{\partial S_{c c}}=\frac{\frac{1}{\left(V+S_{c c}\right)^{2}} \times\left[V-\left(S_{\pi \pi}+S_{\pi s}\right)+\frac{1}{c} \times \phi\left(\lambda^{B} L\right) \frac{S}{L}\right]}{1+\frac{1}{c} \times \frac{\phi^{\prime}\left(\lambda^{B} L\right)}{V+S_{c c}} S}>0
$$

\section{Positive correlation between exchange rate risk and country risk}

$$
\text { If } \begin{aligned}
& \rho_{c s}=\frac{S_{c s}}{S_{c} S_{s}}>0 \\
& \qquad \mathbf{B}=\left(\begin{array}{cc}
V & V+S_{c s} \\
V+S_{c s} & V+S_{c c}+2 S_{c s}
\end{array}\right)
\end{aligned}
$$


and

$$
\mathbf{C}=-\left(\begin{array}{c}
S_{\pi \pi}+S_{\pi s}+S_{c s} \\
S_{\pi \pi}+S_{\pi s}+S_{c c}+S_{c s}
\end{array}\right)
$$

and

$$
\left(\begin{array}{l}
\lambda \\
\gamma
\end{array}\right)=\left(\begin{array}{c}
\frac{\left(S_{\pi \pi}+S_{\pi s}\right)}{S_{c s}^{2}}+\frac{1}{c} \times \frac{S_{c c}}{S_{c s}} \times \frac{E\left(r^{F}-r^{C F}\right)}{V-\frac{S_{c s}^{2}}{S_{c c}}} \\
1-\frac{S_{c c}}{S_{c s}} \times \frac{\left(S_{\pi \pi}+S_{\pi s}\right)}{V-\frac{S_{c s}^{2}}{S_{c c}}}-\frac{1}{c} \times V S_{c c} \times \frac{E\left(r^{F}-r^{C F}\right)}{V-\frac{S_{c s}^{2}}{S_{c c}}}
\end{array}\right)
$$

Thus, offshorization now becomes binding $(\lambda<\gamma)$ iff

$$
S_{c c}>\frac{1}{c} \times \frac{E\left(r^{F}-r^{C F}\right)}{K}=\frac{1}{c} \times \frac{\phi\left[L-\left(1-\lambda_{u}\right) S\right]}{K}
$$

where

$$
K=\frac{V-\left(S_{\pi \pi}+S_{\pi s}\right)-\rho_{c s}\left[\rho_{c s} S_{s s}+\frac{S_{s}}{S_{c}}\left(S_{\pi \pi}+S_{\pi s}\right)\right]}{V+\rho_{c s} S_{s} S_{c}}>0
$$

increases with $\rho_{c s}$. 